http://dx.doi.org/10.18778/1643-0700.20.09

Jarosław STULCZEWSKI*

\title{
DZIAŁALNOŚĆ PREZYDIUM GROMADZKIEJ RADY NARODOWEJ W SIKUCINIE (1954-1958)
}

\begin{abstract}
Streszczenie. Gromadzka Rada Narodowa w Sikucinie została utworzona w wyniku reformy administracyjnej w 1954 r. W jej skład weszły obszary wsi: Sikucin, Boczki Reduchów, Kotlinki z gminy Szadek. Gromadzka Rada Narodowa swoje uchwały realizowała za pośrednictwem prezydium, które było kolegialnym organem wykonawczym i zarządzającym rady narodowej. Zakres kompetencji władz gromady obejmował m.in. uchwalanie rocznego budżety gromady, zatwierdzanie i odwoływanie sołtysów, organizację skupu żywca, zboża, ziemniaków i mleka oraz zbieranie podatków, sprawy związane z organizacją prac polowych, budową dróg i szkolnictwem. Kolejnymi przewodniczącymi Prezydium GRN w Sikucinie byli: Ludwik Otocki, Wacław Król i Władysław Siekierski. Gromada została zlikwidowana 31 grudnia $1958 \mathrm{r}$.
\end{abstract}

Słowa kluczowe: Sikucin, gromada, rady narodowe

Celem artykułu jest przedstawienie działalności i funkcjonowania w latach 1954-1958 Gromadzkiej Rady Narodowej (dalej: GRN) w Sikucinie, najniższego ogniwa administracji państwowej obejmującego swym zasięgiem kilka wsi. W granicach dzisiejszej gminy Szadek do chwili jej utworzenia z dniem 1 stycznia 1973 r. działało sześć gromad: w Górnej Woli, Krokocicach, Prusinowicach, Przatowie, Sikucinie i Wielkiej Wsi. Główną bazę źródłową do artykułu stanowi zespół archiwalny Prezydium Gromadzkiej Rady Narodowej w Sikucinie, przechowywany w Archiwum Państwowym w Łodzi Oddział w Sieradzu. Zachował się on w szczątkowej, fragmentarycznej ilości $(0,07 \mathrm{mb})$, gdyż w zespole odnaleźć możemy jedynie

* Jarosław Stulczewski, archiwista, działacz społeczno-kulturalny oraz ruchu rekonstrukcyjno-historycznego, prezes Zarządu Towarzystwa Przyjaciół Zduńskiej Woli, 98-220 Zduńska Wola, ul. Mickiewicza 4, e-mail: jaroslaw.stulczewski@o2.pl. 
niepełne protokoły sesji i protokoły posiedzeń prezydium ${ }^{1}$. To w poważnym stopniu utrudnia szczegółowe omówienie wszystkich aspektów funkcjonowania sikucińskiej rady narodowej. W poprzednim tomie „Biuletynu Szadkowskiego” została zaprezentowana działalność Prezydium GRN w Prusinowicach².

GRN była w Polsce Ludowej najniższym organem władzy państwowej na terenach wiejskich, działającym na podstawie ustawy z dnia 25 września $1954 \mathrm{r}$. o reformie podziału administracyjnego wsi i powołaniu gromadzkich rad narodowych $^{3}$. Celem ustawodawcy było „włączenie coraz szerszych mas pracujących do udziału w rządzeniu państwem, rozwijaniu ich twórczej inicjatywy i aktywności dla pomnażania dobrobytu i kultury wsi". Na mocy tej ustawy dotychczasowe działania gminnych rad narodowych i ich organów przejęły gromadzkie rady narodowe. Zakres ich kompetencji w późniejszych latach wyznaczała także ustawa z dnia 25 stycznia 1958 r. o radach narodowych ${ }^{4}$ oraz ustawa $\mathrm{z}$ dnia 28 czerwca 1963 r. o zmianie ustawy o radach narodowych ${ }^{5}$.

Pozycja ustrojowa rad narodowych w Polsce, przejęta z modelu radzieckiego, kwalifikowała je jako organy reprezentujące władzę państwową. Stworzono strukturę hierarchicznie podporządkowanych organów przedstawicielskich państwa (Sejm oraz wojewódzkie, powiatowe i gromadzkie rady narodowe). Rada narodowa wyłoniona w drodze wyborów miała z jednej strony reprezentować interesy społeczności lokalnej, a z drugiej pełnić funkcje terenowego organu władzy państwowej, reprezentującego interesy państwa jako całości. Ci sami radni, mieli być jednocześnie rzecznikami swych wyborców i władzy zwierzchniej. W terenie nie istniał zatem rozdział centralnej władzy państwowej i lokalnej - samorządowej. Obie te funkcje pełnić miała jedna i ta sama instytucja ${ }^{6}$.

GRN jako terenowy organ władzy i administracji państwowej początkowo miała bardzo wąskie kompetencje. Zajmowała się głównie wykonywaniem zarządzeń władz powiatowych w zakresie działalności gospodarczej, rozwoju produkcji rolnej, zaspokajania potrzeb socjalnych i kulturalnych mieszkańców oraz realizacją obowiązków względem państwa. Uchwalała także budżet, zarządzała mieniem gromadzkim, prowadziła sprawy meldunkowe i inne sprawy administracyjne. Budżet gromadzki powiązany był z budżetem powiatowym.

Gromadę Sikucin z siedzibą GRN w Sikucinie utworzono w powiecie sieradzkim - jako jedną z 8789 gromad na obszarze Polski - na mocy uchwały nr 38/54 Wojewódzkiej Rady Narodowej w Łodzi z dnia 4 października 1954 r.

1 Archiwum Państwowe w Łodzi Oddział w Sieradzu (dalej: APŁOS), Prezydium Gromadzkiej Rady Narodowej w Sikucinie, sygn. 557/1-6.

2 Zob. J. Stulczewski, Działalność Prezydium Gromadzkiej Rady Narodowej w Prusinowicach (1954-1961), „Biuletyn Szadkowski” 2019, t. 19, s. 93-106.

Dz.U. 1954, nr 43, poz. 191.

Dz.U. 1958, nr 5, poz. 16.

Dz.U. 1963, nr 28, poz. 164.

6 J. Drygalski, J. Kwaśniewski, (Nie)realny socjalizm, Warszawa 1992, s. 185. 
W spawie podziału na nowe gromady powiatu sieradzkiego ${ }^{7}$. W skład jednostki weszły wsie: Sikucin, Boczki, Reduchów i Kotlinki z gminy Szadek. Gromadzka rada narodowa liczyła 11 członków $^{8}$. Radnych wybierała w okręgach wyborczych ludność gromady na trzyletnią kadencję. W roku 1957 ilość radnych zwiększono do 12 , a rok później do 15.

5 grudnia 1954 r. odbyły się wybory do gromadzkich rad narodowych. W skład GRN w Sikucinie zostali wybrani: Bronisław Barylski, Rozalia Białek, Piotr Cymerman, Ludwik Fret, Wacław Król, Janina Majchrowska, Mieczysław Oliński, Ludwik Otocki, Krystyna Siekierska, Władysław Siekierski i Józef Sznajder9. Pierwsza inauguracyjna sesja GRN została zwołana 20 grudnia 1954 r. Ze względu na brak zachowanego protokołu z zebrania, nie możemy szerzej omówić przebiegu posiedzenia. Zapewne wybrani radni złożyli ślubowanie.

Realizacją uchwał GRN zajmowało się prezydium - kolegialny organ wykonawczy i zarządzający rady narodowej. Prezydium wybierano spośród radnych w głosowani tajnym. W latach 1954-1957 Prezydium GRN w Sikucinie było pięcioosobowe: przewodniczący, zastępca przewodniczącego, sekretarz oraz dwóch członków.

W skład prezydium mogły wchodzić osoby spoza rady. Wybór przewodniczącego rady podlegał zatwierdzeniu przez prezydium rady stopnia wyższego. Do zadań prezydium rady narodowej należało przygotowanie i zwoływanie sesji rady, uchwalanie planu gospodarczego i budżetu oraz rozpatrywanie okresowych sprawozdań z ich wykonania. Prezydium mogło podejmować uchwały w obecności co najmniej połowy swego składu. Prezydium było podporządkowane: własnej radzie oraz Prezydium Powiatowej Rady Narodowej (dalej: PRN) w Sieradzu.

Na pierwszego przewodniczącego Prezydium GRN w Sikucinie wybrano Ludwika Otockiego urodzonego 3 grudnia 1911 r. w Łodzi, syna Wacława i Władysławy z Baryłów, zamieszkałego na stałe w Boczkach. Ojciec jego, w 1905 r. jako członek PPS brał udział w rewolucji na terenie Łodzi. Do roku 1926 Ludwik uczęszczał do szkoły powszechnej w Rossoszycy, gdzie ukończył 4 klasy. W latach 1926-1933 u swojego ojca terminował jako uczeń murarski, a także cho-

7 Uchwała Nr 38/54 Wojewódzkiej Rady Narodowej w Łodzi z dnia 4 października 1954 r. w sprawie podziału na nowe gromady powiatu sieradzkiego; w ramach Zarządzenia $\mathrm{Nr}$ Or. V-167/1/54 Prezydium Wojewódzkiej Rady Narodowej w Łodzi z dnia 22 listopada 1954 r. w sprawie ogłoszenia uchwał Wojewódzkiej Rady Narodowej w Łodzi z dnia 4 października 1954 r., dotyczących reformy podziału administracyjnego wsi. Zob. Dziennik Urzędowy Wojewódzkiej Rady Narodowej w Łodzi z dnia 1 grudnia 1954 r., nr 11, poz. 39.

8 Uchwała Nr LIV/330/54 Prezydium Powiatowej Rady Narodowej w Sieradzu z dnia 2 października 1954 r. w sprawie ustalenia liczby członków gromadzkich rad narodowych. Zob. Dziennik Urzędowy Wojewódzkiej Rady Narodowej w Łodzi z dnia 9 października 1954 r., nr 9, poz. 36.

9 Ogłoszenie Okręgowej Komisji Wyborczej w Sieradzu dla wyborów do gromadzkich rad narodowych z dnia 7 grudnia 1954 r. Zob. Dziennik Urzędowy Wojewódzkiej Rady Narodowej w Łodzi z dnia 28 grudnia 1954 r., nr 12, poz. 88. 
dził na kursy wieczorowe, kończąc 7 klas szkoły powszechnej. Od roku 1929 do chwili powołania do służby wojskowej należał do Ochotniczej Straży Pożarnej w Rossoszycy. 5 marca 1933 r. został wcielony do armii polskiej. Służył w 31 Pułku Strzelców Kaniowskich w Łodzi w plutonie artylerii. Służbę ukończył w 1935 r. w stopniu kaprala. Następnie zawarł związek małżeński z Zofią Skąpską i pracował w zawodzie murarskim na terenie powiatu sieradzkiego. Od roku 1939 do lipca tego samego roku był zatrudniony w firmie budowlanej Rajchert w Lodzi jako podmajstrzy murarski. 10 lipca 1939 r. został powołany na ćwiczenia rezerwy 31 PSK. W wrześniu 1939 r. brał udział w wojnie obronnej Polski, przemierzając szlak frontowy na linii Kutno-Lowicz-Sochaczew i Prusy Wschodnie. Awansowany do stopnia plutonowego, 29 września 1939 r. dostał się do niewoli niemieckiej we wsi Kampinos ${ }^{10}$ pod Warszawą. Został wywieziony do obozu jenieckiego Stalag II D w Starogardzie, gdzie przebywał do momentu ucieczki w roku 1942. Powrócił do Boczek, rok ukrywając się przed niemieckimi władzami okupacyjnymi. Następnie na podstawie fałszywych dokumentów otrzymał pracę jako murarz na sieradzkim poligonie wojskowym. Pracował jako podmajstrzy murarski w firmie R. Majer. Przez Adama Banacha został zaangażowany do konspiracyjnej działalności w Batalionach Chłopskich. W 1944 r. został wzięty do pracy przy kopaniu okopów, skąd na dwa tygodnie przed wkroczeniem Armii Czerwonej uciekł. W styczniu 1945 r. brał udział w rozbrajaniu Niemców na terenie Rossoszycy, organizując w dniu 21 stycznia miejscowy Posterunek Milicji Obywatelskiej (MO). Przyjęty w szeregi MO, pracował początkowo w Rossoszycy, skąd w grudniu 1945 r. został skierowany na szkołę polityczną do Łodzi, którą ukończył z wynikiem bardzo dobrym i przydzielony został do pracy w Komendzie Powiatowej MO w Sieradzu w charakterze instruktora ds. polityczno-wychowawczych. W 1946 r. za czynny udział i walkę z hitlerowskim okupantem został odznaczony Brązowym Krzyżem Zasługi. Skierowany w 1948 r. do pracy w Komendzie Powiatowej MO w Końskich, początkowo pracował tam jako instruktor powiatowy, a od $1949 \mathrm{r}$. był zastępcą komendanta powiatowego ds. polityczno-wychowawczych. Zwolnił się na własną prośbę w roku 1950 i powrócił w rodzinne strony. Przez rok pracował jako referent personalny w Gminnej Spółdzielni „Samopomoc Chłopska” (dalej: GS) w Szadku. W latach 1951-1953 jako sukcesor prowadził ponad 3-hektarowe gospodarstwo rolne w Boczkach. Następnie do momentu wyboru na przewodniczącego GRN w Sikucinie był kierownikiem Gminnego Ośrodka Maszynowego w Szadku. Od 1945 r. był członkiem Stronnictwa Ludowego, a od maja 1945 r. Polskiej Partii Robotniczej, następnie PZPR (m.in. w latach 1949-1951 sekretarz POP w GS) ${ }^{11}$.

Na pierwszej sesji dokonano także wyboru pozostałych członków prezydium. Zastępcą przewodniczącego Prezydium GRN został Mieczysław Oliński

10 W życiorysie błędna nazwa Kampinów.

11 Archiwum Łódzkiego Urzędu Wojewódzkiego w Łodzi (dalej: AŁUW), Akta osobowe Ludwika Otockiego, sygn. 249/1749, k. b. pag. 
(ur. 1.01.1932 r. w Sikucinie, zam. Boczki) ${ }^{12}$, sekretarzem Piotr Cymerman (ur. 6.05.1923 r. w Reduchowie, zam. Kotlinki) ${ }^{13}$, a członkami Wacław Król i Józef Sznajder ${ }^{14}$.

Podczas kolejnego zebrania 10 stycznia 1955 r. wybrano członków kolegium orzekającego w składzie: Ludwik Otocki, Bronisław Barylski, Józef Sznajder, Janina Majchrowska i Mieczysław Wąż. Do komisji sanitarno-porządkowej wybrano: Mieczysława Węża, Franciszka Wieruszewskiego, Wacława Króla, Józefa Michalskiego, Piotra Jabłońskiego. Dokonano wyboru także przewodniczących i członków poszczególnych czterech komisji stałych GRN. Komisja dróg i urządzeń: przewodniczący - Bronisław Barylski, członkowie - Mieczysław Wąż, Franciszek Wieruszewski, Stanisław Pietrzak. Komisja rolna: przewodniczący - Ludwik Fret, członkowie - Janina Majchrowska, Józef Michalski, Bolesław Ciupa, Adam Pietrzak. Komisja oświaty, kultury i zdrowia: przewodniczący - Rozalia Białek, członkowie - Bolesław Jędrasiak, Zofia Kegler, Stanisław Niedźwiecki. Komisja finansowa i budżetu: przewodniczący - Krystyna Siekierska, członkowie - Władysław Siekierski, Stanisław Wierciocha, Teresa Kołakowska, Władysław Kozioł ${ }^{15}$.

Na wspomnianym wcześniej zebraniu przewodniczący poruszył sprawę resztówek, czyli reszty gruntów z budynkami pozostałymi po parcelacji majątków ziemskich w Boczkach i Kotlinach. Radny Bronisław Barylski stwierdził, że resztówkę w Kotlinach należy przydzielić Komitetowi Założycielskiemu Spółdzielni Produkcyjnej. Radni więc uchwalili przydział resztówki w Kotlinach wspomnianemu komitetowi. Sprawę gruntów w Boczkach pozostawiono do kolejnego zebrania, gdyż tamtejszy komitet był w trakcie organizacji. Stwierdzono, że jeśli nie będzie się on w stanie zawiązać, resztówka zostanie zagospodarowana przez Prezydium GRN w Sikucinie ${ }^{16}$. Według oceny radnych, miejscowe Prezydium GRN miało dobre warunki lokalowe do pracy, lepsze niż inne gromady jak np. w Górnej Woli.

Podstawowym zadaniem gromady w latach 1954-1958 była organizacja skupu żywca, zboża, ziemniaków, mleka, zabezpieczenie zbiórki podatków i organizacja prac polowych. Cel był jasno wyznaczony - ściągnąć jak najwięcej żywności i podatków z gromady. Po 1958 r. kompetencję GRN zostały rozszerzone o zagadnienia związane $\mathrm{z}$ budową dróg i szkolnictwem.

GRN w Sikucinie obradowała na sesjach składających się z jednego lub kilku posiedzeń zwoływanych przez prezydium, podczas których rozpatrywano najważniejsze sprawy dotyczące gromady, uchwalano roczne budżety, zatwierdzano i odwoływano sołtysów. Często przedmiotem posiedzeń prezydium GRN była

\footnotetext{
12 Tamże, Akta osobowe Mieczysława Olińskiego, sygn. 249/1732, k. b. pag.

13 Tamże, Akta osobowe Piotra Cymermana, sygn. 249/367, k. b. pag.

14 APŁOS, sygn. 557/4, k. b. pag.

15 Tamże, sygn. 557/1, k. b. pag.

16 Tamże.
} 
sprawa zaległości w wykonaniu obowiązkowych dostaw zboża, żywca, mleka i ziemniaków przez miejscowych chłopów.

26 lutego 1955 r. w wyniku permanentnej nieobecności na sesjach Władysława Siekierskiego, który oświadczył, że nie będzie w nich uczestniczył ze wzglądu na osobę przewodniczącego, wybrano nowego radnego. Został nim Eugeniusz Jarczak z Boczek ${ }^{17}$. Kierowniczka Szkoły Podstawowej w Sikucinie Zofia Kegler skarżyła się na złe warunki mieszkaniowe. Wyjaśniała, że zmuszona była do mieszkania u prywatnego gospodarza Bolesława Kaczmarka, a na okres zimowy nie mogła nawet zakupić węgla w lokalnej GS. Radni w drodze uchwały upoważnili przewodniczącego do podjęcia działań w tym zakresie.

Na posiedzeniu Prezydium GRN 16 marca 1955 r. dokonano wyboru Komitetu Odbudowy Warszawy w składzie: Ludwik Otocki (przewodniczący Prezydium GRN), Piotr Cymerman (sekretarz gromadzki), Zofia Kegler (kierownik Szkoły Podstawowej w Sikucinie), Krystyna Siekierska (kierownik sklepu GS w Sikucinie), Władysław Wiśniewski (prezes gromadzkiej GS w Kotlinkach), Józef Olczyk (inkasent podatkowy gromady) i Stanisław Wiercioch (leśniczy lasów Reduchów) ${ }^{18}$.

24 października 1955 r. w skład GRN dokooptowano jednego radnego z powodu rezygnacji z mandatu i funkcji zastępcy przewodniczącego Mieczysława Olińskiego. Większością głosów nowym radnym został Roman Kobusiewicz pracownik Prezydium GRN w Sikucinie. Dokonano także wyboru nowego zastępcy przewodniczącego powierzając tą funkcję Józefowi Sznajderowi, dotychczasowemu członkowi prezydium ${ }^{19}$.

W latach 1954-1955 Prezydium GRN podjęło się zadania wyremontowania domu mieszkalnego w Kotlinach, zajmowanego przed siedem ubogich rodzin. Jednak koszty tego przedsięwzięcia były na tyle duże, że zrezygnowano z dalszej pracy. Należy także odnotować, że w tym okresie na terenie gromady powstały 2 kółka rolnicze we wsi Kotliny i Boczki. Na jej terenie znajdowała się, pozyskana dzięki staraniom radnych, maszyna pogomowska, która służyła do pracy miejscowym rolnikom. Na rzece Pichnie wybudowano most, a przy lokalu prezydium pobudowano szopę. Chłopi ze wsi Boczki nawieźli żwirem ok. $1000 \mathrm{~m}$ drogi, rolnicy z Reduchowa $2 \mathrm{~km}$ drogi, a mieszkańcy Sikucina i Jamna przystąpili do remontu drogi wiodącej od szosy Sikucin do wsi Jamno. Dzięki GRN na terenie wcześniej wspomnianej miejscowości, udało przeprowadzić się elektryfikację gospodarstw. Gromada wsparła finansowo budowę remizy strażackiej w Sikucinie. Ubolewano nad brakiem osiągnięć na polu kulturalnym. Wprawdzie istniała gromadzka bibliotek publiczna w Sikucinie i punkt biblioteczny w Reduchowie, to jednak mieszkańcy żalili się nad brakiem świetlicy wiejskiej. Komisja oświaty, kultury i zdrowia działająca przy GRN zorganizowała w 1956 r. szkołę wieczorową,

\footnotetext{
17 Tamże.

18 Tamże, sygn. 557/4, k. b. pag.

19 Tamże, sygn. 557/1, k. b. pag.
} 
która umożliwiła 14 osobom ukończenie 7 klas z zakresu szkoły podstawowej. Dodatkowo na terenie gromady powstał zespół czytelniczy, którego zadaniem stało się propagowanie czytelnictwa oraz ciekawych książek ${ }^{20}$.

Głównym tematem kwietniowego posiedzenia prezydium w roku 1956 była sprawa działalności na terenie gromady dwóch spółdzielni produkcyjnych w Boczkach i Kotlinach, które nie do końca wypełniały postawione im zadania. Spółdzielnia Produkcyjna w Kotlinach posiadała 37,85 ha i liczyła 11 członków. Jej przewodniczącym był Bronisław Barylski. Z kolei druga spółdzielnia zlokalizowana w Boczkach kierowana przez Józefa Olczyka gospodarowała na 29 ha i skupiała 8 członków. Celem polepszenia pracy, rozrostu i umocnienia obu spółdzielni prezydium podjęło uchwalę zalecającą przewodniczącym spółdzielni odbywanie częstszych narad i zebrań spółdzielców, prowadzenie akcji uświadamiającej rolników o wyższości gospodarki zespołowej nad indywidualną, a także agitację rolników do członkostwa w spółdzielni ${ }^{21}$.

Na posiedzeniu GRN w dniu 19 listopada 1956 r. radni postanowili z dniem 30 listopada 1956 r. odwołać z funkcji przewodniczącego Ludwika Otockiego w związku z niewywiązywaniem się z powierzonych mu obowiązków. Nowym przewodniczącym został wybrany Wacław Król. Wybrano także nowego sekretarza gromadzkiego. W miejsce ustępującego Piotra Cymermana został wybrany Roman Kobusiewicz. 14 marca 1957 r. wybrano nowe siedmioosobowe kolegium orzekające w składzie: przewodniczący - Wacław Król (przewodniczący GRN), zastępca przewodniczącego - Daniela Krzymińska (referent meldunkowy), członkowie - Józef Sznajder (zastępca przewodniczącego GRN), Janina Majchrowska (radna), Tadeusz Puś (rolnik), Piotr Cymerman (radny), Franciszek Dzienniak (rolnik) ${ }^{22}$.

28 sierpnia 1957 r. z funkcji sekretarza GRN z przyczyn osobistych zrezygnował Roman Kobusiewicz. Na sesji 5 września 1957 r. dyskutowano nad słusznością działalności miejscowej GRN. Na podstawie odbytych zebrań wiejskich w sprawie nowego podziału administracyjnego, mieszkańcy wsi Boczki i Reduchów wypowiedzieli się za odejściem z GRN w Sikucinie. Radny Piotr Cymerman był za rozwiązaniem miejscowej gromady i przyłączenia miejscowych wsi do GRN w Wielkiej Wsi i Rossoszycy. Z kolei inny radny był za pozostawieniem rady w Sikucinie ze zmniejszonym personelem samego prezydium. W sprawie likwidacji lub pozostawienia gromady wywiązała się szersza dyskusja. Obecny na sesji zastępca przewodniczącego Prezydium PRN w Sieradzu Jan Pawlak wyjaśnił powody likwidacji w powiecie sieradzkim małych rad gromadzkich, które nie miały perspektywy rozwoju gospodarczego i kulturalnego. Do takich należała gromada w Sikucinie, która nawet finansowo nie dawała sobie rady ze swoimi wydatkami. Stwierdził również, że tworzenie w przeszłości takich małych rad jak

\footnotetext{
20 Tamże, sygn. 557/2, k. b. pag.

21 Tamże, sygn. 557/5, k. b. pag.

22 Tamże, sygn. 557/2, k. b. pag.
} 
Sikucin było paradoksem. W dodatku gromada nie wywiązywała się należycie z obowiązkowych dostaw i nałożonych podatków co stawiało ją na szarym końcu w skali całego powiatu sieradzkiego ${ }^{23}$.

Wspomniane wcześniej zebrania wiejskie służyły rozpatrywaniu spraw dotyczących poszczególnych wsi, omawianiu kwestii poprawy warunków gospodarowania, warunków bytowych i kulturalnych mieszkańców wsi, rozwoju produkcji rolniczej, upowszechnieniu wiedzy rolniczej, poprawie warunków sanitarnych i porządku na wsi. Stanowiły także forum, na którym zgłaszano postulaty. Zebrania wiejskie były poświęcane wyjaśnianiu celów i wytycznych polityki władz, omawiano wykonywanie obowiązków wobec państwa. Były także miejscem składania sprawozdań z działalności gromadzkiej rady narodowej. W zebraniu wiejskim mogli uczestniczyć mieszkańcy danej wsi, którym przysługiwało prawo wyboru do gromadzkiej rady narodowej ${ }^{24}$.

1 października 1957 r. zwiększono liczbę radnych sikucińskiej gromady z 12 do 13. Na zebraniach wiejskich odbytych we wrześniu tego samego roku, większością głosów została wybrana do GRN Jadwiga Przybylska - delegat ds. skupu $^{25}$. Nowej radnej dodatkowo zostały powierzone obowiązki sekretarza gromadzkiego, w miejsce powstałego wakatu po rezygnacji Kobusiewicza ${ }^{26}$.

Sesja gromadzka, która odbyła się 30 listopada 1957 r. miała szczególny przebieg, w związku z otrzymaną przez Prezydium PRN w Sieradzu skargą na przewodniczącego Prezydium GRN w Sikucinie Wacława Króla. Wynikało z niej, że przewodniczący razem z Lucjanem Rutą, agronomem rejonowym i Józefem Kłakiem, instruktorem Komitetu Powiatowego PZPR w godzinach służbowych 30 września tego samego roku wzięli udział w libacji alkoholowej u rolnika Adama Kozłowicza we wsi Sikucin. W czasie jej trwania Lucjan Ruta na polecenie Wacława Króla spisał z córką gospodarza, Pauliną Kozłowicz fikcyjną umowę o pracę w miejscowym prezydium. Umowę miał podpisać przewodniczący. W efekcie końcowym Kozłowiczówna nie została zatrudniona i napisała skargę do Wojewódzkiej Rady Narodowej (dalej: WRN) w Łodzi. Przeprowadzone dochodzenie przez pracownika Wydziału Kadr i Szkolenia WRN z udziałem instruktora organizacyjnego Prezydium PRN potwierdziło całkowicie stawiane zarzuty.

Obecny na zebraniu Jan Pawlak, zastępca przewodniczącego Prezydium PRN w Sieradzu przekazał stanowisko Prezydium WRN oraz PRN o odwołanie przewodniczącego z zajmowanego stanowiska. Wśród radnych i zaproszonych gości

23 Tamże.

24 E. Sokalska, Organizacja lokalnego aparatu administracyjnego $w$ Polsce $w$ latach 1957-1975, „Studia Prawnoustrojowe” 2005, nr 4, s. 50.

25 Jadwiga Przybylska, ur. 30 marca 1936 r. w miejscowości Jamno, szwaczka od 5 marca 1954 r. Spółdzielni Pracy „Lipcowy Zryw” w Zduńskiej Woli Oddział w Szadku, następnie delegat ds. skupu PRN, od 24 marca 1958 r. sekretarz gromadzki w Sikucinie. Zob. AŁUW, Akta osobowe Jadwigi Przybylskiej, sygn. 249/1969, k. b. pag.

26 APŁOS, sygn. 557/2, k. b. pag. 
wywiązała się ożywiona dyskusja. Wacław Król podczas sesji tłumaczył się następująco:

(...) przyszli do Prezydium Gr. R.N. ob. Kłak Józef i Ruta Lucjan $i$ wraz z nimi udałem się do ob. Kozłowicz gdzie byt już stót zastawiony wódka i zakaska. Ruta napisat zaangażowanie do pracy w Prezydium ob. Kozłowicz, ja zaś popisałem, ale nie zdawałem sobie sprawy z tego sprawy. Wódke piłem, ale się o nia nie domagatem $^{27}$.

Przedstawiciel Wydziału Kadr WRN z Łodzi Zagajewski stwierdził:

(...) umowa nawet zawarta ustnie jest umowa ważna. Faktem byto także pijaństwo u ob. Kozłowiczów. Przewodniczący Gr. R. N. ob. Król - jako przedstawiciel władzy ludowej tamat praworządność ludowa, poniżyt autorytet Przewodniczacego Gr. R. N., zawiódt zaufanie swych wyborców. Jest winien i powinien ponieść karę. Rada musi wyciagnać odpowiednie wniosk ${ }^{28}$.

Część radnych i osób zaproszonych była przeciwna odwołaniu przewodniczącego, a jedynie za udzieleniem mu nagany. Po wymianie zdań, ostatecznie Wacław Król sam złożył rezygnację z zajmowanej funkcji. W głosowaniu tajnym, na 8 obecnych na zebraniu radnych, 5 było za usunięciem dotychczasowego przewodniczącego, a 3 osoby były temu przeciwne. W związku z powstałym wakatem, na kolejnej sesji 4 grudnia podjęto nieudaną próbę wyboru nowego włodarza gromady. Zgłoszeni radni: Władysław Siekierski, Józef Sznajder i Bronisław Barylski - zrzekli się kandydowania, tłumacząc się w różny sposób. Zgłoszony radny Piotr Cymerman mimo, że wyraził zgodę na kandydowanie nie otrzymał wystarczającej ilości głosów ${ }^{29}$. Dodatkowo zbliżał się koniec roku, w tym także upływała trzyletnia kadencja radnych. Taki stan utrzymał się do lutowych wyborów do rad gromadzkich, a gromadą zarządzał do tego czasu zastępca przewodniczącego Józef Sznajder.

2 lutego 1958 r. po raz drugi odbyły się wybory do rad narodowych. Gromada w Sikucinie została podzielona na dwa okręgi wyborcze. Wybrano 15 nowych radnych. Z okręgu wyborczego nr 1 radnymi zostali: Józef Ciepłowski, Tomasz Kopczyński, Ignacy Marczak, Jan Mikołajczyk, Józef Olczyk, Jan Snowarski, Stanisław Wiercioch, Helena Wieruszewska. Z okręgu nr 2 do rady weszli: 
Franciszek Dzienniak, Józef Michalski, Jadwiga Przybylska, Józef Przybylski, Tadeusz Puś, Władysław Siekierski, Teresa Zawierta ${ }^{30}$.

Pierwsza sesja nowej rady odbyła się 25 lutego 1958 r. w lokalu Prezydium GRN w Sikucinie. Spotkanie otworzył dotychczasowy zastępca przewodniczącego Prezydium GRN Józef Sznajder. Po ślubowaniu radnych dokonano wyboru nowego przewodniczącego i dwóch członków Prezydium GRN w Sikucinie. Nowym przewodniczącym został Władysław Siekierski, a członkami prezydium Józef Olczyk i Franciszek Dzienniak. Dokonano także wyboru członków poszczególnych komisji gromadzkich (tab. 1) ${ }^{31}$.

Tablica 1. Skład stałych Komisji GRN w Sikucinie w 1958 roku

\begin{tabular}{|c|c|c|c|c|c|}
\hline L.p. & Nazwisko i imię & Radny & $\begin{array}{c}\text { Przynależność } \\
\text { partyjna }\end{array}$ & Zakład pracy & Zawód \\
\hline \multicolumn{6}{|c|}{ Komisja Finansowo-Budżetowa } \\
\hline 1 & Zawiera Teresa & tak & PZPR & $\begin{array}{c}\text { szkoła } \\
\text { podstawowa }\end{array}$ & nauczyciel \\
\hline 2 & Mikołajczyk Jan & tak & bezpartyjny & gospod. rolne & rolnik \\
\hline 3 & Puś Tadeusz & tak & bezpartyjny & gospod. rolne & rolnik \\
\hline 4 & Pietrzak Adam & nie & bezpartyjny & gospod. rolne & rolnik \\
\hline 5 & Krupiński Marian & nie & bezpartyjny & gospod. rolne & rolnik \\
\hline \multicolumn{6}{|c|}{ Komisja Rolnictwa } \\
\hline 1 & Kopczyński Tomasz & tak & bezpartyjny & gospod. rolne & rolnik \\
\hline 2 & Snowarski Jan & tak & bezpartyjny & gospod. rolne & rolnik \\
\hline 3 & Zagata Stanisław & nie & bezpartyjny & gospod. rolne & rolnik \\
\hline 4 & Stępień Ignacy & nie & bezpartyjny & gospod. rolne & rolnik \\
\hline 5 & $\begin{array}{c}\text { Masłowski } \\
\text { Czesław }\end{array}$ & nie & bezpartyjny & gospod. rolne & rolnik \\
\hline \multicolumn{6}{|c|}{ Komisja Oświaty, Kultury i Zdrowia } \\
\hline 1 & Ciepłowski Józef & tak & bezpartyjny & wł. gospod. & rolnik \\
\hline 2 & Caban Marian & nie & bezpartyjny & $\begin{array}{c}\text { szkoła } \\
\text { podstawowa }\end{array}$ & nauczyciel \\
\hline 3 & Jędrasiak Bolesław & nie & bezpartyjny & wł. gospod. & rolnik \\
\hline 4 & $\begin{array}{c}\text { Dzienniak } \\
\text { Stanisław } \\
\end{array}$ & nie & bezpartyjny & wł. gospod. & rolnik \\
\hline 5 & Mazurkiewicz Piotr & nie & bezpartyjny & wł. gospod. & rolnik \\
\hline
\end{tabular}

30 Ogłoszenie Okręgowej Komisji Wyborczej w Sieradzu dla wyborów do gromadzkich rad narodowych z dnia 2 lutego 1958 r. Zob. Dziennik Urzędowy Wojewódzkiej Rady Narodowej w Łodzi z dnia 15 kwietnia 1958 r., nr 2, poz. 6.

31 APŁOS, sygn. 557/3, k. b. pag. 


\begin{tabular}{|c|c|c|c|c|c|}
\hline L.p. & Nazwisko i imię & Radny & $\begin{array}{c}\text { Przynależność } \\
\text { partyjna }\end{array}$ & Zakład pracy & Zawód \\
\hline \multicolumn{7}{|c|}{ Komisja Mienia i Urządzeń Gromadzkich } \\
\hline 1 & Przybylski Józef & tak & PZPR & PGRN & $\begin{array}{c}\text { pracownik } \\
\text { umysłowy }\end{array}$ \\
\hline 2 & Michalski Józef & tak & ZSL & wł. gospod. & rolnik \\
\hline 3 & Dobrowolski Józef & nie & bezpartyjny & wł. gospod. & rolnik \\
\hline 4 & Sznajder Józef & nie & bezpartyjny & wł. gospod. & rolnik \\
\hline 5 & $\begin{array}{c}\text { Wieruszewski } \\
\text { Franciszek }\end{array}$ & nie & ZSL & wł. gospod. & rolnik \\
\hline
\end{tabular}

Źródło: APŁOS, Prezydium Gromadzkiej Rady Narodowej w Sikucinie, sygn. 557/3, k. b. pag.

Nowy przewodniczący Władysław Siekierski był mieszkańcem wsi Jamno, gdzie przyszedł na świat 10 maja 1903 r. jako syn Ignacego i Małgorzaty z Czapińskich. Od roku 1910 uczęszczał do szkoły elementarnej w Sikucinie, gdzie ukończył 4 klasy. W 1923 r. został powołany do odbycia służby wojskowej. Następnie powrócił do gospodarstwa rodzinnego przy którego prowadzeniu pomagał rodzicom. Po zawarciu związku małżeńskiego w roku 1933 razem z żoną prowadził własne gospodarstwo rolne. W okresie okupacji niemieckiej pracował jako robotnika rolny. Od roku 1945 był członkiem Stronnictwa Ludowego, a następnie Zjednoczonego Stronnictwa Ludowego (ZSL). W 1947 r. został wybrany przez ludność wsi Kotlinki na sołtysa, którym pozostawał do momentu zniesienia tego urzędu w roku $1954^{32}$.

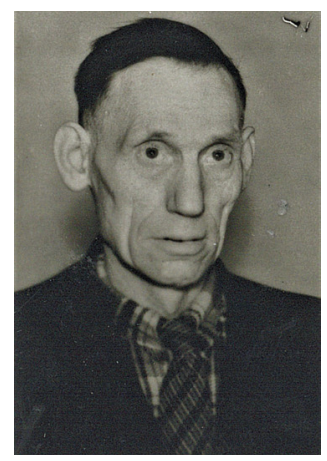

Fot. 1. Władysław Siekierski - przewodniczący Prezydium GRN w Sikucinie Źródło: AŁUW, Akta osobowe Władysława Siekierskiego, sygn. 249/2088, k. b. pag.

32 AŁUW, Akta osobowe Władystawa Siekierskiego, sygn. 249/2088, k. b. pag. 
Na kolejnej marcowej sesji, na wniosek radnego Franciszka Dzienniaka przeniesiono gromadzką bibliotekę z lokalu prywatnego do siedziby Prezydium GRN w Sikucinie. Na zebraniach rady zazwyczaj omawiano sprawy gospodarcze, związane m.in. z zaopatrzeniem rolników w nawozy sztuczne, udzielaniem kredytów, poborem opłat, przydziałem materiałów budowlanych, poprawą warunków bytowych i kulturalnych (w tym radiofonizacją i elektryfikacją wsi). Tematem obrad była także realizacja obowiązkowych dostaw i rozliczanie rolników z zaległości w tym zakresie oraz sprawy związane z podatkiem gruntowym.

W kwietniu 1958 r. odbyły się wybory na sołtysów miejscowości wchodzących w skład gromady. Zniesiony dotychczas urząd sołtysa został przywrócony na mocy ustawy z $1958 \mathrm{r}^{33}$, w świetle której zebranie wiejskie zwołane przez przedstawiciela gromadzkiej rady narodowej wybierało sołtysa na okres trzech lat spośród osób uprawnionych do udziału w zebraniu wiejskim. Zadaniem sołtysa było zapewnienie stałej łączności między wsią a gromadzką radą narodową i jej prezydium. Wybór sołtysa podlegał zatwierdzeniu przez gromadzką radę narodową. GRN lub Prezydium PRN mogły odwołać sołtysa, który nie wywiązał się ze swych obowiązków lub dopuścił się przestępstwa. Sołtys miał działać w myśl wskazań gromadzkiej rady narodowej, czuwać nad wykonywaniem przez mieszkańców wsi obowiązków wynikających z przepisów prawa oraz uchwał GRN i jej prezydium oraz prezentować postulaty wsi wobec prezydium gromadzkiej rady narodowej. Sołtysi brali udział w okresowych naradach sołtysów, zwoływanych przez prezydium GRN. Zniesienie w 1954 r. urzędu sołtysa - reprezentanta samorządu wiejskiego - miało poniekąd związek z organizowaniem spółdzielni produkcyjnych. Urząd ten - według powszechnej opinii - nie był potrzebny, a nawet mógł stanowić przeszkodę w realizacji polityki władz państwowych na wsi. W latach 1954-1958 pojawił się urząd pełnomocnika gromadzkiej rady narodowej, który jednak po czterech latach został zlikwidowany, a w jego miejsce ponownie przywrócono urząd sołtysa. Sołtysami miejscowości wchodzących w skład gromady Sikucin w roku 1958 zostali: w Boczkach - Jan Mikołajczyk, w Kotlinkach - Stanisław Dzienniak, w Sikucinie - Wacław Król, w Reduchowie - Marian Krupiński ${ }^{34}$.

Na wrześniowej sesji GRN powróciła ponowie sprawa likwidacji gromady w Sikucinie ze względu na małą ilość mieszkańców oraz brak możliwości rozwoju jakiegokolwiek rozwoju przemysłu. Dodatkowo 26 listopada przewodniczący Władysław Siekierski złożył prośbę do PRN w Sieradzu o zwolnienie go ze zajmowanego stanowiska ze względu na pogarszający się stan zdrowia ${ }^{35}$. Radni

33 Dz.U. 1958, nr 5, poz. 16.

34 APŁOS, sygn. 557/3, k. b. pag.

35 Władysław Siekierski zmarł 5 grudnia 1987 r. w Jamnie. 
na sesji zwołanej trzy dni później jednomyślnie zagłosowali za pozostaniem Siekierskiego na funkcji włodarza gromady ${ }^{36}$.

W 1955 r. odbyło się łącznie jedenaście sesji rady narodowej, tyle samo w roku 1957. Ze względu na brak zachowanych protokołów posiedzeń za rok 1956 i częściowo za rok 1958 nie jesteśmy w stanie określić ile razy wówczas radni się zebrali. To sprawia, że nie posiadamy także wiedzy o szczegółowym przebiegu sesji we wspomnianym okresie.

Wprowadzony w roku 1954 podział kraju na gromady był całkowicie sztuczny. Powszechne dostrzegano wady przeprowadzonej tej reformy administracyjnej, przede wszystkim utworzenie zbyt wielu małych gromad. Jedną z nich była właśnie ta w Sikucinie. Zajmowała niewielki obszar i liczyła niewielu mieszkańców. Ostatecznie 27 grudnia 1958 r. Prezydium PRN w Sieradzu zatwierdziło zniesienie z dniem 31 grudnia 1958 r. GRN w Sikucinie. Jej teren podzielono między dwie gromady. Miejscowości: wieś i kolonię Sikucin, kolonię Hamentów, osadę młyńską Reduchów-Babieniec, wieś, kolonię i parcelę Reduchów, wieś i osadę leśną Jamno, wieś i kolonię Kotlinki oraz wieś i parcelę Kotliny włączono do GRN w Wielkiej Wsi. Z kolei miejscowości: wieś i parcelę Boczki, wieś i osadę Boczki Kobylskie, wieś, osadę, kolonię i osadę młyńską Kobyla Chmielowa, a także kolonię Zacharki przyłączono do GRN w Rossoszycy ${ }^{37}$.

\section{Bibliografia}

\section{Źródła}

Archiwum Łódzkiego Urzędu Wojewódzkiego w Łodzi:

Akta osobowe Piotra Cymermana, sygn. 249/367.

Akta osobowe Mieczystawa Olińskiego, sygn. 249/1732.

Akta osobowe Ludwika Otockiego, sygn. 249/1749.

Akta osobowe Jadwigi Przybylskiej, sygn. 249/1969.

Akta osobowe Władystawa Siekierskiego, sygn. 249/2088.

Archiwum Państwowe w Łodzi Oddział w Sieradzu, Prezydium Gromadzkiej Rady Narodowej w Sikucinie, sygn. 557.

\section{Źródła drukowane}

Dziennik Urzędowy 1954, nr 43, poz. 191.

Dziennik Urzędowy 1958, nr 5, poz. 16.

36 AŁUW, Akta osobowe Władystawa Siekierskiego, sygn. 249/2088, k. b. pag.

37 M. Bandurka, Zmiany administracyjne i terytorialne ziem województwa łódzkiego w XIX i XX wieku, Łódź 1995, s. 147. 
Dziennik Urzędowy 1963, nr 28, poz. 164.

Dziennik Urzędowy Wojewódzkiej Rady Narodowej w Łodzi 1954, nr 9, poz. 36.

Dziennik Urzędowy Wojewódzkiej Rady Narodowej w Łodzi 1954, nr 11, poz. 39.

Dziennik Urzędowy Wojewódzkiej Rady Narodowej w Łodzi 1954, nr 12, poz. 88.

Dziennik Urzędowy Wojewódzkiej Rady Narodowej w Łodzi 1958, nr 2, poz. 6.

\title{
Opracowania
}

Bandurka M., Zmiany administracyjne i terytorialne ziem województwa tódzkiego w XIX i XX wieku, Łódź 1995.

Drygalski J., Kwaśniewski J., (Nie)realny socjalizm, Warszawa 1992.

Sokalska E., Organizacja lokalnego aparatu administracyjnego $w$ Polsce $w$ latach 1957-1975, „Studia Prawnoustrojowe” 2005, nr 4.

[Artykuł wpłynął: kwiecień 2020; akceptacja: czerwiec 2020]

\section{ACTIVITY OF THE PRESIDING COMMITTEE OF THE PEOPLE'S DISTRICT COUNCIL IN SIKUCIN (1954-1958)}

\begin{abstract}
Summary
The People's District Council in Sikucin was formed in consequence of the administrative reform in 1954. It comprised the villages of Sikucin, Boczki Reduchów and Kotlinki in the municipality of Szadek. The resolutions of the People's District Council were implemented by the presiding committee, which was its executive and managing body. The powers of the committee included the passing of the annual budget of the district, the confirming and dismissing of village administrators, organisation of the purchasing of cattle for slaughter, grain, potatoes and milk, tax collecting, and matters connected with organisation of field cultivation, road construction and education. Successive presidents of the committee were Ludwik Otocki, Wacław Król and Władysław Siekierski.
\end{abstract}

Keywords: Sikucin, district, People's councils 